\title{
First distribution records of Calamagrostis abnormis (Poaceae, Agrostidinae) from Sichuan and Xizang Provinces, China
}

\begin{abstract}
First distribution records of Calamagrostis abnormis (Poaceae, Agrostidinae) from Sichuan and Xizang Provinces, China. - Acta Mus. Siles. Sci. Natur., 67: 59-61, 2018.

Abstract: Calamagrostis abnormis, a Sino-Himalayan species, is reported with new distribution records in southern Sichuan and southeastern Xizang, China. The species was previously recorded to be distributed in Yunnan and western Guizhou in China, Nepal, Bhutan, India, and Northwest Vietnam. The general distribution map of C. abnormis is presented.
\end{abstract}

Key words: Asia, Deyeuxia, distribution, Sino-Himalayan region

\section{Introduction}

A comprehensive taxonomic treatment of Calamagrostis s. lato (including Asian Deyeuxia) is now being prepared for Flora of Pan-Himalaya (Paszko, unpubl. data). Detail revision of herbarium collections has revealed thirty-four new provincial records of Calamagrostis s. lato in China, including three new country records (Paszko \& Ma 2011; Paszko \& Chen 2013; Paszko 2012, 2014 a, b, 2015, 2016; Paszko \& Pendry 2013; Paszko \& Soreng 2013; Paszko \& Chen in Nobis et al. 2014, 2015; Paszko et al. 2013, 2016, 2017). Here, we are recorded the first provincial records of Calamagrostis abnormis (Hook. f. emend. Paszko) Shukla from southern Sichuan and southeastern Xizang, China.

\section{Material and methods}

The first author studied specimens of Calamagrostis abnormis from the herbarium of Institute of Botany of Chinese Academy of Sciences in Beijing (PE). New revised localities of C. abnormis are listed in the text and shown on map (Fig. 1) produced using SimpleMappr (http://www.simplemappr.net/). The collections were georeferenced based on locality information and their estimated coordinates are given in square brackets.

\section{Results}

Taxonomic treatment

Calamagrostis abnormis (Hooker f.) Shukla, 1996

Deyeuxia abnormis Hooker, 1896, s. str. emend. Paszko in Paszko \& Soreng, 2013.

Taxonomic note: Calamagrostis abnormis has complicated nomenclature, Paszko \& Soreng (2013) and Paszko et al. (2017) have provided complete synonymy.

General distribution: BHUTAN (Deothang, Thimphu, Punakha, Tongsa, Bumthang, Mongar, Tashigang), CHINA (W Guizhou, S Sichuan, SE Xizang, Yunnan), INDIA (Arunachal Pradesh, Manipur, Meghalaya), NEPAL (Dolkha, Ramechhap, Sankhuwasabha, Solu Khumbu), VIETNAM (Lao Kay) (Fig. 1).

Distribution note: Calamagrostis abnormis is a widespread Sino-Himalayan species occurring in the central and eastern Nepal, Bhutan, India, South Central China, and Northwest Vietnam (Handel-Mazzetti 1936; Schmid 1958; Noltie 1999, 2000; Lu et al. 2006; Paszko \& Soreng 2013; Paszko et al. 2017). In China, Calamagrostis abnormis was recorded till now from Yunnan and Guizhou Provinces ( $\mathrm{Lu}$ et al. 2006). Here, its first records are reported from the Dechang County of Sichuan Province and from Cona and Mêdog Counties of Xizang, China. 
Several new localities from Yunnan Province are also listed (Fig. 1). It is distributed mainly in the Yunnan-Guizhou Plateau, with some adjacent localities in the southeastern part of QinghaiTibetan Plateau. The gap between localities at Manipur (NE India) and Longling Co. (Yunnan, China) extents for almost $500 \mathrm{~km}$. The disjunct distribution records of this species are probably due to lack of intensive field work in the areas in the southern slope and western part of the eastern slope of the Himalayas.

\section{Specimens examined:}

CHINA. Sichuan [first record]: Dechang Co., Shanmaqiao, under pine forest, $2700 \mathrm{~m},\left[27.405^{\circ} \mathrm{N}, 102.173^{\circ} \mathrm{E}\right.$ ], 11.07.1959, leg. S.F. Zhu 20300 (PE).

XIZANG [first records]: Cona Co., Lexiang, SE slope, $2530 \mathrm{~m},\left[27.994^{\circ} \mathrm{N}, 91.958^{\circ} \mathrm{E}\right], 08.08 .1974$, leg. QinghaiTibetan Vegetation Team 2526 (PE); Mêdog Co., Gelin Basin, grassland, $1550 \mathrm{~m},\left[29.324^{\circ} \mathrm{N}, 95.334^{\circ} \mathrm{E}\right]$, 12.08.1980, leg. Ecology Plateau Team 14186 (PE).

YunNAN: Binchuan Co., Jizu Mt., Zhujing Temple, Quercus forest, $2300 \mathrm{~m},\left[25.83^{\circ} \mathrm{N}, 100.578^{\circ} \mathrm{E}\right], 22.08 .1963$, leg. NW Yunnan - Jinsha River Team 63-6639 (PE); Dayao Co., Dayao to Desang(?) Mt., 2500 m, [25.726 $\mathrm{N}$, $\left.101.325^{\circ} \mathrm{E}\right], 02.09 .1963$, leg. NW Yunnan - Jinsha River Team 63-6803 (PE); Huize Co.: Liangwang Shan, ca. $20 \mathrm{~km}$ SE of Dongchuan, on new rd. to Zhoatong via Zhehai, scruby Pinus yunnanensis/Alnus nepalensis forest, shrubs and grasses, around corn and tobacco fields, alt. $2080 \mathrm{~m}, 26^{\circ} \mathrm{N}, 103.25^{\circ} \mathrm{E}, 14.09 .1997$, leg. R. Soreng et al. 5290 (PE); Jingdong Co., Ailao Mt., Xujiaba, grassland, riverbank, $2500 \mathrm{~m},\left[24.452^{\circ} \mathrm{N}\right.$, $\left.100.836^{\circ} \mathrm{E}\right], 20.07 .2003$, leg. S.S. Zhou 1555 (PE); Kunming City, Western Hills, Sujia Village, $\left[25.051^{\circ} \mathrm{N}\right.$, $\left.102.702^{\circ} \mathrm{E}\right], 26.10 .1941$, leg. T.N. Liou 19187 (PE); Kunming City, Heilongtan, wet place, streamside, $\left[25.051^{\circ} \mathrm{N}, 102.702^{\circ} \mathrm{E}\right], 19.07 .1954$, leg. Kuming Institute Team 50524 (PE); Longling Co., $3 \mathrm{~km}$ S of Longling Town, $1550 \mathrm{~m},\left[24.59^{\circ} \mathrm{N}, 98.69^{\circ} \mathrm{E}\right], 20.05 .1955$, leg. C.Y. Wu et al. 1281 (PE); Ninglang Co., unknown, $\left[27.288^{\circ} \mathrm{N}, 100.849^{\circ} \mathrm{E}\right], 15.09 .1981$, leg. Tian 108(5) (PE); Shilin Co., Guishan, Xuantiange Temple, at the edge of forest or under the forest along the slope, $2240 \mathrm{~m}, 24.6405833^{\circ} \mathrm{N}, 103.595833^{\circ} \mathrm{E}, 12.08 .2006$, leg. Y.M. Shui et al. 64160 (PE); Shilin Co., near Guishan, $1935 \mathrm{~m}, 24.6545556^{\circ} \mathrm{N}, 103.554222^{\circ} \mathrm{E}, 16.08 .2006$, leg. Y.M. Shui et al. 64422 (PE); Shilin Co., Guishan, Yusheng Village, on the slope of the limestone hills, $2050 \mathrm{~m}, 24.6888611^{\circ} \mathrm{N}, 103.472361^{\circ} \mathrm{E}, 19.08 .2006$, leg. Y.M. Shui et al. 64610 (PE); Shilin Co., Guishan, in evergreen forest on limestone hills slope, $2560 \mathrm{~m}, 24.6275^{\circ} \mathrm{N}, 103.577778^{\circ} \mathrm{E}, 27.08 .2006$, leg. Y.M. Shui et al. 64994 (PE); Wenshan Co., Bozhu Mt., open place on slope, $2550 \mathrm{~m},\left[23.376^{\circ} \mathrm{N}, 104.236^{\circ} \mathrm{E}\right], 28.07 .1993$, leg. Y.M. Shui 3116 (PE); Yongren Co., Zhonghe, wasteland, $2460 \mathrm{~m},\left[26.063^{\circ} \mathrm{N}, 101.674^{\circ} \mathrm{E}\right], 2.08 .1965$, leg. Southwest Expedition Team of CAS 606 (PE).

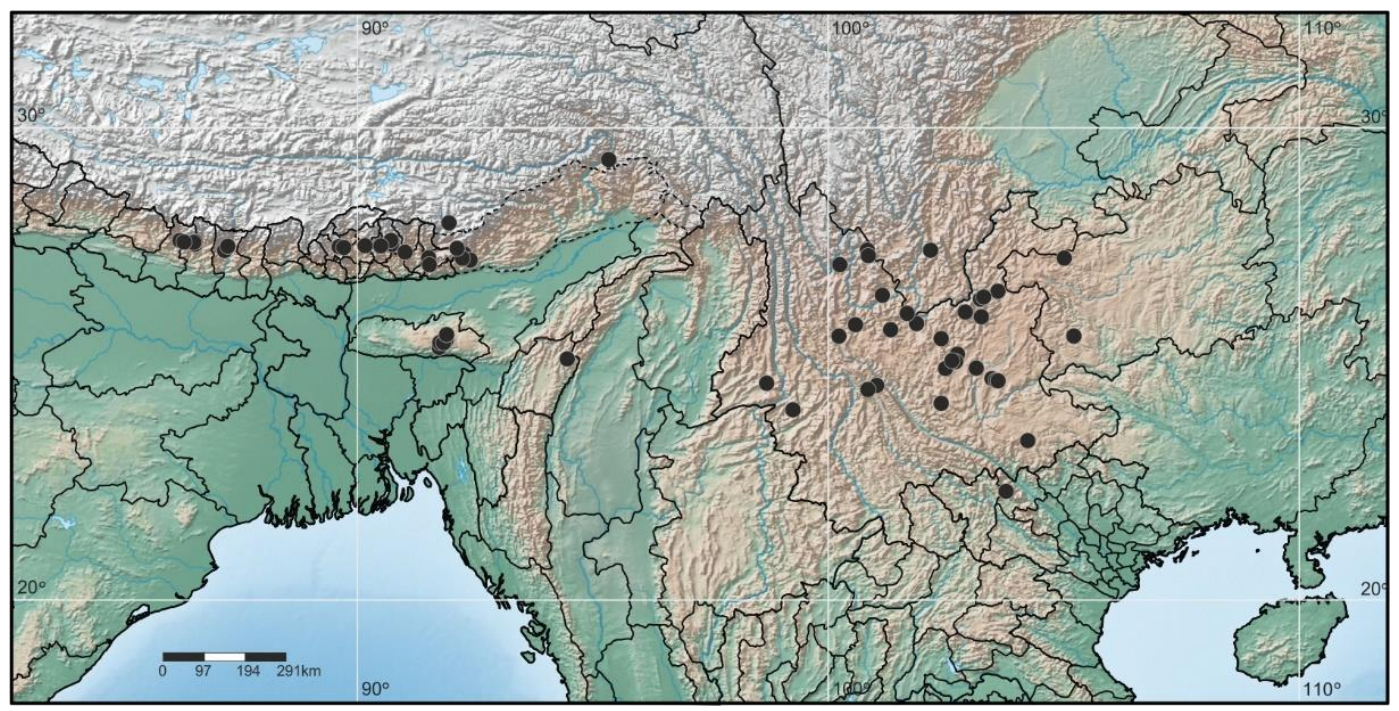

Fig 1: General distribution of Calamagrostis abnormis. 
Acknowledgements: Research visits of Beata Paszko in 2017 to Beijing (PE) was supported by the exchange program between the Polish Academy of Sciences and the Chinese Academy of Sciences. This study was also financed in part from the statutory fund of the W. Szafer Institute of Botany of the Polish Academy of Sciences.

\section{References}

Handel-Mazzetti, H.F. (1936): Botanische Ergebnisse der Expedition der Akademie der Wisssenschaften in Wien nach Südwest-China 1914-1918. VII. Anthophyta. - Symbolae Sinicae 7: 731-1450.

Lu S.L., Chen W.L. \& Phillips S.M. (2006): Deyeuxia. - In: Wu Z.Y., Raven P.H. \& Hong D.Y. (eds) Flora of China: Poaceae 22. Science Press, Beijing \& Missouri Botanical Garden Press, St. Louis, pp 348-359.

Nobis M., Ebel A.L., Nowak A., Paszko B., Bobrov A.A., et al. (2015): Contribution to the flora of Asian and European countries: new national and regional vascular plant records, 4. - Acta Botanica Gallica: Botany Letters 162(4): 301-316.

Nobis M., Ebel A.L., Nowak A., Turginov O.T., Kupriyanov A.N., et al. (2014): Contribution to the flora of Asian and European countries: new national and regional vascular plant records, 2. - Acta Botanica Gallica: Botany Letters 161: 209-221.

Noltie H.J. (1999): Notes relating to the Flora of Bhutan: XXXIX. Gramineae II. - Edinburgh Jornal of Botany 56: $381-404$.

Noltie H.J. (2000): Flora of Bhutan 3(2). The Grasses of Bhutan. Royal Botanic Garden Edinburgh \& Royal Government of Bhutan, Edinburgh.

Paszko B. (2012): Taxonomic revision of Calamagrostis filiformis, C. tripilifera and their allies (Poaceae: Agrostidinae). - Polish Botanical Journal 57(2): 335-346.

- (2014a): Deyeuxia himalaica (Poaceae, Agrostidinae): taxonomy and its first record from Myanmar. - Phytotaxa 156(5): 285-290.

- (2014b): Taxonomic reassessment of Calamagrostis garhwalensis (Poaceae: Agrostidinae). - Phytotaxa 159(3): 211-220.

- (2015): The first record of the Sino-Himalayan species Deyeuxia himalaica in the Yunnan Province, SW China, and three new combinations in Calamagrostis (Poaceae, Agrostidinae). - Polish Botanical Journal 60(2): 141145.

Paszko B. \& Chen W.L. (2013): Deyeuxia sorengii sp. nov. (Poaceae, Agrostidinae) from Qinghai-Tibetan Plateau. - Nordic Journal of Botany 31: 551-555.

Paszko B., Chen W.L. \& Liu B. (2016): Confirmation of Calamagrostis salina in China, previously misidentified as C. macilenta, and notes about C. kokonorica and C. macilenta (Poaceae, Agrostidinae). Phytotaxa 268(4): 251-262.

Paszko B., Chen W.L. \& Szczepaniak M. (2013): Deyeuxia debilis (Poaceae, Agrostidinae): typification, taxonomy and update of the Chinese distribution. - Phytotaxa 135(1): 1-10.

Paszko B., Liu B. \& Ma H.Y. (2017): Calamagrostis (Poaceae, Agrostidinae) in Vietnam. - Polish Botanical Journal 62(2): 213-228.

Paszko B. \& Ma H.Y. (2011): Taxonomic revision of the Calamagrostis epigeios complex with particular reference to China. - Journal of Systematics and Evolution 49: 495-504.

Paszko B. \& Pendry C. (2013): Deyeuxia gaoligongensis (Poaceae: Agrostidinae), a new species from Gaoligong Shan in Yunnan, China. - Phytotaxa 93(1): 40-46.

Paszko B. \& Soreng R.J. (2013): Species delimitation and name application in Deyeuxia abnormis, Agrostis zenkeri, A. pleiophylla and related taxa (Poaceae: Agrostidinae). - Phytotaxa 111(1): 1-26.

Schmid M. (1958): Flore agrostologique de l'Indochine. - Agronomie Tropicale (Nogent-sur-Marne) 13: $304-$ 309.

Authors' addresses: Beata Pas zko, Department of Vascular Plants, W. Szafer Institute of Botany, Polish Academy of Sciences, Lubicz 46, PL-31 512 Kraków, Poland.

corresponding author: b.paszko@botany.pl

Bing Liu, State Key Laboratory of Systematic and Evolutionary Botany,

Institute of Botany, Chinese Academy of Sciences, Beijing 100093, China. 